\title{
Transatlantica
}

Revue d'études américaines. American Studies Journal

1 | 2017

Morphing Bodies: Strategies of Embodiment in

Contemporary US Cultural Practices

\section{A Conversation with Richard Layman}

\section{Benoît Tadié}

\section{(2) OpenEdition}

1 Journals

Electronic version

URL: https://journals.openedition.org/transatlantica/8961

DOI: 10.4000/transatlantica.8961

ISSN: 1765-2766

Publisher

Association française d'Etudes Américaines (AFEA)

\section{Electronic reference}

Benoît Tadié, "A Conversation with Richard Layman", Transatlantica [Online], 1 | 2017, Online since 29 November 2018, connection on 20 May 2021. URL: http://journals.openedition.org/transatlantica/ 8961 ; DOI: https://doi.org/10.4000/transatlantica.8961

This text was automatically generated on 20 May 2021

\section{(c) (1) () $\Theta$}

Transatlantica - Revue d'études américaines est mise à disposition selon les termes de la licence Creative Commons Attribution - Pas d'Utilisation Commerciale - Pas de Modification 4.0 International 


\section{A Conversation with Richard Layman}

\section{Benoît Tadié}

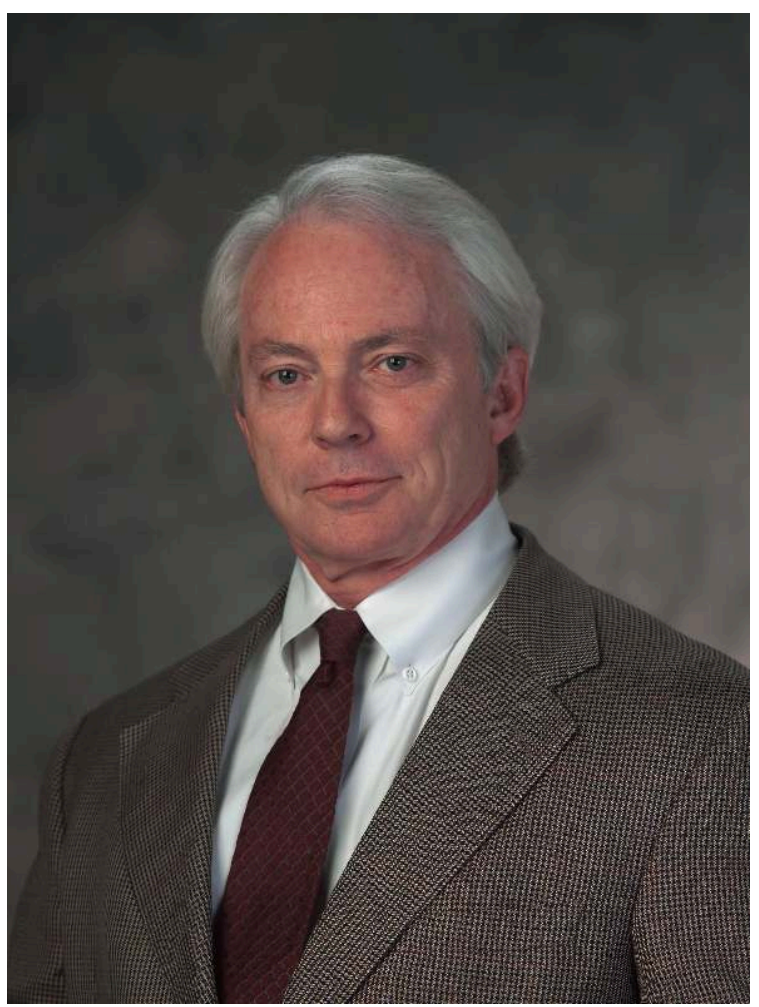




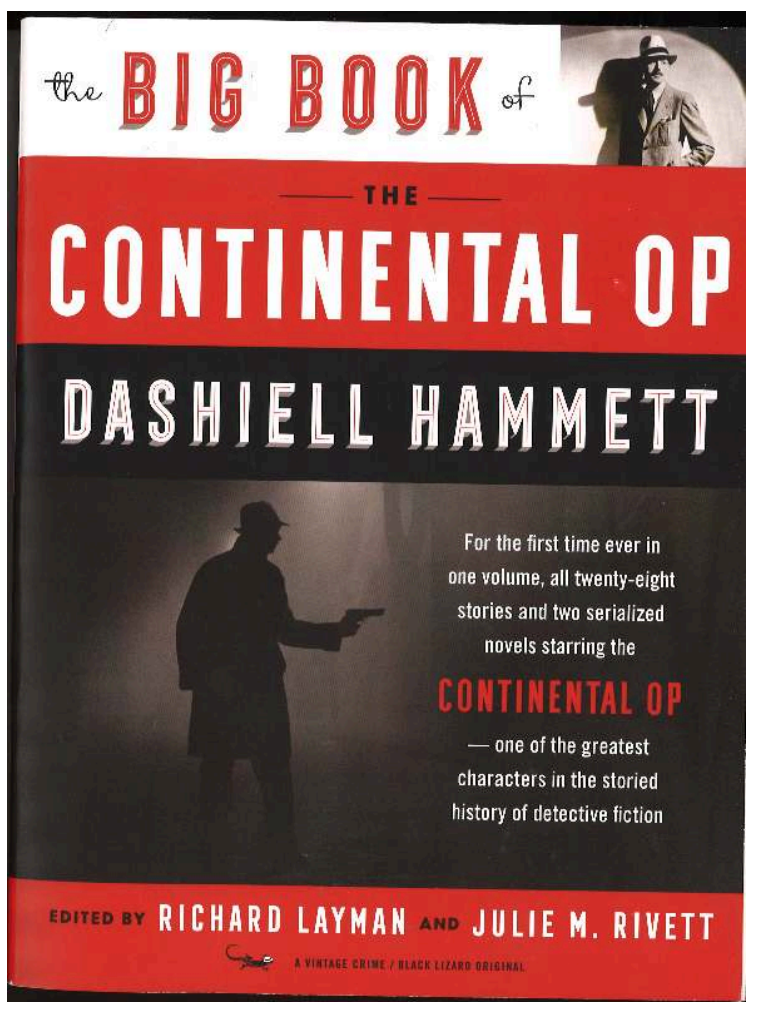

The Big Book of the Continental Op, book cover

\section{Introduction}

Richard Layman is the world's foremost scholar on Dashiell Hammett. Among the twenty books he has written or edited are nine on Hammett, including the definitive bibliography (Dashiell Hammett, A Descriptive Bibliography, 1979), Shadow Man, the first full-length biography (1981), Hammett's Selected Letters (with Julie M. Rivett, Hammett's granddaughter, as Associate Editor, 2001), Discovering The Maltese Falcon and Sam Spade (2005, and The Hunter and Other Stories (2013), with Rivett. His books have twice been nominated for the Mystery Writers of America Edgar Award.

2 With Rivett, he has recently edited The Big Book of the Continental op (Vintage Crime/ Black Lizard, 2017), which for the first time gathers the complete canon of Hammett's first detective, the nameless Continental Op (for Operative). Most of Hammett's Op stories appeared in the pages of Black Mask magazine between October 1923 and November 1930. In a handsome 730-page volume, The Big Book collects all twenty-eight Op stories as well as the original versions of Hammett's first two novels (Red Harvest and The Dain Curse) and the draft of an unfinished Op tale, "Three Dimes."

Hammett revolutionized detective fiction with the Op stories and novels, which were inspired by his experience as an agent with Pinkerton's National Detective Agency between 1915 and 1921. The Op has long been recognized as the quintessential hardboiled detective hero/narrator. Hammett's tales, in which violence is sometimes relieved by comedy, are characterized by a tough and ironic style, realistic settings, swift action and dialogue and a general sense of the absurd. But they also show striking 
innovations in language and plotting and reveal a writer who could, in Raymond Chandler's words, "say almost anything" and "write scenes that never seemed to have been written before."

On the occasion of the publication of this essential collection, we asked Richard Layman to discuss Hammett's literary achievement in the light of his experience as a Hammett scholar and editor.

\section{Questions}

Benoît Tadié: I would like to begin with your work as a biographer. In Shadow Man: The Life of Dashiell Hammett (Harcourt Brace Jovanovich, 1981), you have written what is arguably the best and most reliable biography of Hammett. What difficulties did you face when writing it? Are there gaps in Hammett's life which you had trouble filling? Do we now know more about his life than four decades ago?

Richard Layman: I wrote Shadow Man thirty-six years ago. I have since learned a lot about him, about research, and about writing. I think I could do a much better job now, but, that said, I'm still proud of Shadow Man. I faced significant obstacles. First, Lillian Hellman was alive then, and she advised her friends who had known Hammett not to speak to me. She issued a similar dictum to the Hammett family-Hammett's wife and both of his daughters were still living when the book was published-and they obeyed. As a result, I was left with the public record and those friends of Hammett's outside Hellman's circle as resources for my book. That set of circumstances is not all bad. It forced a hard objectivity in my treatment of Hammett on the one hand; and on the other, I was denied access to the family and close friends, their insights into his behavior and motivations and personality. I also missed the opportunity to study the invaluable cache of letters and other items in the family's possession, which is now in the Dashiell Hammett Collection at the Thomas Cooper Library, University of South Carolina. It took fifteen years after Shadow Man for me to meet the family and develop the close working relationship that has resulted.

There are gaps in Shadow Man, and I made mistakes, which I have tried to correct in the books I have been involved with since. Given the obstacles, I'll stand by Shadow Man, but I would like the opportunity to rewrite it, given world enough and time.

BT: Apart from his daughter Jo's valuable and moving memoir (Dashiell Hammett: A Daughter Remembers, which you edited with Julie M. Rivett), the only extensive firsthand account we have of Hammett's life and character is to be found in Lillian Hellman's introduction to The Big Knockover, published in 1965. How do you feel about Hellman's narrative? Does it fit in with your own impression of Hammett? Do you believe it gives us the "real" Hammett?

RL: It is a serious mistake to ignore Hellman on Hammett, but it is an equally serious mistake to believe everything she wrote about him. Hellman was a fabricator. As she announced with the title of her memoir Pentimento, she shaped her experiences and her biographical portraits for effect. So it was with Hammett. She created an image of him that served her own purposes.

I suspect that some of that impulse was a product of the time in which she lived. She was active in leftist politics, which was dangerous during the first half of her career, and she was more clandestine in her behavior than Hammett was. While she was working hard for party causes with him, she did so stealthily, while he was open 
about his political affiliations. Hammett was a member of the Communist Party USA and didn't deny it. He showed his membership card to his daughter; his membership in the party was announced in the Chicago Tribune. While she grandstanded selfrighteously before the House Committee on UnAmerican Activities then mischaracterized her position as groundbreaking, Hammett suffered the consequences without complaint and paid most of the cost.

BT: Considering that Hammett died more than half a century ago, in 1961, why is it that so many of his stories, including the previously-unpublished material you have collected in Return of the Thin Man and The Hunter, have only very recently come to light?

RL: When Hellman was alive, she controlled Hammett's literary rights, as per provisions in his will. She died in 1984. Her will established the Dashiell Hammett Literary Property Trust, with three trustees. They were indifferent to their responsibilities and neglected them shamefully. I proposed publishing the previously unpublished Hammett works, which Hellman deposited at the Harry Ransom Center, University of Texas at Austin, in the early 1990s, and the trustees not only failed to respond to my proposal, one of them disingenuously claimed to have discovered the material himself. Only when the trust was secured from Hellman's trustees for the benefit of the family, with Hammett's grandson Evan Marshall, me, and later Hammett's granddaughter, Julie M. Rivett, did we gain the right to publish what we saw fit. We have been active in making his works available since then.

BT: The Continental Op seems to have been modeled on a Pinkerton operative named James Wright, one of Hammett's colleagues in Baltimore before 1915 and 1918. What can you tell us about him? In what ways did he contribute to the Op's characterization?

RL: There was no James Wright. That story comes from a statement Hammett made in Ellery Queen's Mystery Magazine, and it was one of his private jokes. James Wright was an alias that had been used by Pinkerton agents working under cover since the nineteenth century. To say the Op was based on James Wright was to say he was based on Pinkerton agents.

BT: Hammett's case reports for Pinkerton have apparently disappeared. Is there any hope that they may one day surface again? Do you think that they might have shaped his style or provided the nucleus for some of his stories?

RL: I doubt Hammett's Pinkerton reports will ever turn up. The Pinkerton files are at the Library of Congress. They are divided by geographical division, and the story is that the Baltimore office papers, which would have included Hammett's records, were destroyed by fire. The LOC files are interesting in that they give a sense of what a report looked like, and they provide information about such matters as pay and assignments in other divisions, but there is no mention of Hammett-or other Baltimore office operatives that I could find. I did locate a copy of the Pinkerton code of conduct from the early 1920s, found behind a file cabinet in the San Francisco Pinkerton office, where Hammett worked then, after it was vacated. A copy of that document is in the Hammett Collection at the University of South Carolina.

BT: As you write in Shadow Man, the Pinkertons were historically well-known for their activities as union busters, "breaking strikes, controlling strikers, and safeguarding scab workers who crossed picket lines." (11) Interestingly, none of this is reflected in the Op stories, not even in Red Harvest where the plot grows out of the crushing of a miners' strike after World War I. Considering that Hammett wanted to give a true picture of the detective 
business, and that the Continental Agency seems based on Pinkerton's, how would you account for this omission?

RL: Pinkerton was involved in strikebreaking, particularly in the West and in Appalachia, but that was only one part of their operation. Pinkerton services were broad, and the company was organized by the type of service they offered-one division worked on jewel thefts, another bank robberies, another on race-track corruption, and so on. Hammett's work in Baltimore seems to have been involved with combatting various types of larceny. I know of no hard evidence that Hammett was involved in strikebreaking, but we do know he chased bandits of various stripes. There is, of course, Hellman's claim that he was offered \$5000 to assassinate IWW activist Frank Little, but to me that has all the marks of Hellman's sensationalistic fabrication. I don't believe it. So, to answer your question, I think Hammett did give an accurate account of how a detective went about his business, even if the situations the op faces were aggrandized for the purposes of fiction. Most Pinkertons weren't strikebreakers.

BT: In your introduction to the third section ("The Shaw Years") of The Big Book of the Continental Op, you write that Pinkerton's "had the first national fingerprint file," that "its operatives drew on far better national records than most of any police force of the nation at the time," and that they hunted for "crooks of all descriptions, who could move freely from jurisdiction to jurisdiction to avoid the grasp of local police departments." (363) It seems that Pinkerton's almost represented an early prototype of the FBI. Is this power reflected in Hammett's Op stories? Does it help explain their novelty as opposed to classical mystery stories?

RL: Pinkerton agents worked for hire. They didn't so much fight crime as they pursued crooks and solved problems for people with the means to pay for what might be called justice. A major reason for the success of Pinkerton and the other national detective agencies is that they weren't bound by jurisdiction, and they had a national organization. A major difference between Hammett's Op stories and the Golden Age detectives is that the Op is a pro, working more or less by agency rules; the Golden Age detectives were often amateurs. And, of course, the Op works in the mean streets.

BT: It seems to me, also, that the national dimension of Pinkerton's activities is reflected in Hammett's Op stories in indirect ways. As an example, there is the sequence in the fourth part of Poisonville where the Continental Op dreams that he is hunting for an unknown woman through "half the streets in the United States," from "Gay Street, Mount Royal Avenue in Baltimore, Colfax Avenue in Denver," etc., all the way to "Victoria Street in Jacksonville" (602). It's a weird episode; I don't know how you interpret it but it might perhaps suggest, among other things, that the stage and scope of crime fiction are now national rather than local.

RL: I agree with your reading. An effect of the drug-induced dream sequence is to establish a history for the Op. He's not a local; he's not a tyro; he has a history; and he suffers occasional weaknesses, like taking laudanum, that leave him vulnerable.

BT: At the same time, this strange chapter in Poisonville, by giving direct access to the Op's tormented unconscious, also shows the kind of new psychological territory where Hammett was taking detective fiction. Is this what Joseph T. Shaw, who edited Black Mask from 1926 to 1936, meant when, as you recall, he insisted that his writers provide "recognizable human character in three-dimensional form" (362)?

RL: Maybe so. Hammett was a polymath with a serious interest in science, philosophy, psychology, and criminology. He did his homework. I would guess that what Shaw 
was suggesting was a type of realism that would bring characters to life, as opposed to the stock figures that populated most pulp fiction of the time. One way Hammett accomplished that was to show the Op's humanity, which he had been attempting to a lesser degree for about three years before Poisonville. In the novel, the op experiences the full tension created by the demands of professionalism on the one hand and temptations of human emotion on the other.

BT: I would now like to turn, more specifically, to The Big Book of the Continental Op and to the Op stories as they appeared in Black Mask. The collection has justly been hailed in the American press as magnificent. I quite agree and believe it answers a triple need: first, it brings together a fragmented corpus of stories which, we now realize for the first time, is huge; second, it offers a chronological perspective on the evolution of the Op's stories, and of Hammett's style, throughout his most creative years; and third, it gives us, at long last, the original texts of his first two novels, Red Harvest and The Dain Curse, as they appeared in Black Mask between 1927 and 1929. The collection is divided into three sections, "The Sutton Years" (1923-1924), "The Cody Years" (1924-1926), and "The Shaw Years" (1926-1930), corresponding to the three editors under whom Hammett worked for Black Mask. How important were these editors for Hammett? Did they recognize him as superior to the other Black Mask writers? Did they help him to develop as a writer?

RL: As the arrangement of the Big Book suggests, I think the role editors played in Hammett's career was fundamental. Hammett had to write to make a living; to get published he had to write what his editors would accept. There are two elements to consider: content and style. There is evidence that Hammett tried to break away from writing detective fiction, but he had to put bread on the table; the content was imposed upon him to a large degree. His genius is that he was able to create enduring fiction within the boundaries he was forced to accept.

Before Shaw and the editors at Knopf, Hammett did not have the benefit of first-rate editors. H.L. Mencken dismissed him when he began writing and directed him toward the pulps, regarded as the playground of hacks. Publication was easy there and then, and the standards were low, but they paid regularly if not lavishly. Hammett defaulted to writing about what he knew, detective work. When he began writing for Black Mask, his stories were primarily procedural, because that was what Sutton would accept. Then came Cody and the emphasis on Action, and More Action. Hammett's stories became increasingly violent-because that is what Cody accurately believed Black Mask readers wanted. Shaw was more sophisticated in his tastes; he gave Hammett his head, and that's when his genius took over, melding content and style into literature.

Hammett was able to craft action stories that transcended the vulgar tastes of his editors. He gave Sutton and to a larger degree Cody the action they demanded in a writing style that was witty, instructive, exciting, and satisfying. His characters were real, not action figures. The result is that he became the most popular of the Black Mask writers, and Black Mask became the most popular pulp of the 1920s and 1930s.

With regard to development, I think Sutton and Cody may deserve credit for not allowing Hammett to indulge his tendency toward laziness. But Shaw deserves the credit for giving him his head, and that's when his talent began to show in it fullness.

BT: What about Black Mask readers? Is there any evidence that they recognized a great writer in Hammett? Or would you agree with Raymond Chandler, who said that "Hammett 
had style, but his audience didn't know it, because it was in a language not supposed to be capable of such refinements"?

RL: Hammett was the most popular of the Black Mask writers of his day. Did the readers regonize the breadth of his talent? Who knows; probably not. Black Mask appealed to blue-collar readers, but their appreciation is no less significant because they lacked the critical vocabulary to express it.

BT: Was Hammett close to other Black Mask writers of the 1920s, such as Carroll John Daly, Erle Stanley Gardner, Tom Curry, William Rollins, Raoul Whitfield or Frederick Nebel? Was he an influence upon them? Or they upon him?

RL: Black Mask was a national magazine, edited in New York. Hammett was in San Francisco and his communication with the editors was through correspondence. He was acquainted with Daly; Gardner was an assistant editor at Black Mask, who seems to have responded to Hammett's submissions; Hammett was friends with Whitfield later. But I am not aware of any significant social interaction among Black Mask contributors. But Hammett's influence was undeniable, sometimes beneficially, sometimes not. Hammett said that no one was responsible for inspiring as much bad writing as he was.

BT: Some reviewers have argued that The Big Book of the Continental Op shows Hammett gradually turning simplistic pulp fiction into literature. Personally, I am rather struck by the literary quality and absence of naivety or melodramatic effects of even the early stories. The opening lines of the first Op story, "Arson Plus," are very good, as are those of the December 1923 story, "Bodies Piled Up," which I can't resist from quoting: "The Montgomery Hotel's regular detective had taken his last week's rake-off from the hotel bootlegger in merchandise instead of cash, had drunk it down, had fallen asleep in the lobby, and had been fired." (47) It seems to me that Hammett's qualities, including humor, narrative drive and the ability to sketch out a corrupt system in a few words, are already well in evidence here. Do you, however, see important changes in Hammett's writing throughout these seven years? Is there an evolution in the Op's character or behavior? What are your own favorite stories in the collection?

RL: I agree heartily with your observation. I would argue that the development of his talent is evidenced by his ability to sustain those qualities you mention throughout a story. My favorite story is "The Golden Horseshoe," but I have always had a special a feeling for Elvira in "The House in Turk Street" who changes her name to Jeanne Delano in the linked story, "The Girl with the Silver Eyes." Of course, "The Big Knockover" and "\$106,000 Blood Money" are important milestones in his development. And the novels are unbeatable. There are a lot of candidates for my favorite. I almost forgot "The Main Death," with that scene where the adulterous nineteen-year-old bride of the effeminate antiques dealer at the center of the plot is pictured reading The Sun Also Rises.

BT: In such stories as "The Gutting of Couffignal" and "This King Business," Hammett seems to have experimented with political intrigue and/or international settings. What do you make of these stories? Do you see them as minor variations on the genre or do you feel that, with them, Hammett was seriously trying to take the detective story in a new direction? I would also like to ask you the same question regarding "Corkscrew," an interesting story that seems to bring detective fiction back to the Wild West.

RL: In both "Gutting of Couffignal" and "This King Business" I think Hammett was fictionalizing material in the newspapers. "The Gutting of Couffignal" is, of course, most important for its rendering of the scene perfected at the end of The Maltese Falcon, when the Op attempts to explain what it means to be a detective. "This King 
Business" is a rather tedious (I think) fictionalization of Americans' attempts to buy aristocratic status and to impose their good intentions on others. I think "Corkscrew" is an attempt to write for the western pulps-just another market.

BT: Let us now come to one of the highlights of this collection: the first version of Hammett's Red Harvest, as published in Black Mask between November 1927 and February 1928 under the title Poisonville. What strikes me, first of all, is the fact that the word "novel" is never used in the short texts (presumably written by Joseph T. Shaw) that introduce each of the four episodes in the Black Mask version, and which are reprinted in the collection. Was Shaw unaware that the four episodes constituted a novel? Did he avoid presenting or marketing the sequence as a novel for any specific reason?

RL: I don't know the answer, but I will guess. Hammett had been writing linked stories for Black Mask for a while, and I suspect that initially the serially published Poisonville might have been regarded as just another linked story by the Black Mask editorial team. That assumption is more evident in the case of The Dain Curse, which seems to me clearly three stories (in four parts) linked together.

BT: As you point out, there are many differences between Poisonville and Red Harvest, as published two years later by Knopf. For example, the removal, in the Knopf version, of the blowing-up of the chief of police's office in the City Hall (586-587 in The Big Book), for which the chief is himself responsible and which mangles and kills at least two of his own officers, seems a great loss to me. Would you agree with E. R. Hagemann's opinion that the Black Mask version is superior?

RL: Ed Hagemann was a friend and an astute critic. I agree with him in some respects. I think the dialogue in Poisonville is often sharper than in the novel, and I think the Knopf editing was sometimes excessive and tone deaf, but in other cases, the book improves on the language of the magazine. Mrs. Knopf was right, in my judgment, in her complaint that the magazine version goes overboard with the violence, and the plot is maybe more complicated than necessary. But both versions sparkle, and I don't have much criticism for either.

BT: There are other interesting differences between Poisonville and Red Harvest. Thus, a reference to "Machiavelli" ("old Elihu didn't know his Machiavelli," 530) is altered to "Italian history" in the Knopf version. The date of the miners' strike is moved from 1919 (530) to 1921. Also, the year when the Op goes to Poisonville, (1927 in the first version, 527), is deleted in the Knopf version. Do you see any reason for such changes? Was Hammett himself responsible for them?

RL: I think the Knopf editor, probably Harry Bloch, was being a bit officious. Why change the reference to Machiavelli? Because the editor assumed the reader wouldn't know who he was is a reasonable assumption. Why change the date of the miners' strike? Don't know. Maybe some literal minded blue-penciller remembered the Blair Mountain Strike in West Virginia in 1921 and was trying to reference that.

Knopf editors were historically irresponsible regarding dates in Hammett's novels. In the mid 1970s the Vintage paperback of The Maltese Falcon changed the dates in the novel to comport with the 1941 movie.

BT: How would you compare the two versions of The Dain Curse? Is the Knopf one superior to the Black Mask version, in your view?

RL: When The Dain Curse was in production, Hammett complained about the editing and insisted that his work not be mangled by editors and copyeditors. I think he more or less got his way there, and the changes between the BM version and the book 
are more likely to be Hammett's. I'd go with the book, which, as I recall, is only slightly bowdlerized.

BT: Hammett called The Dain Curse "a silly story." Do you agree? It seems that he was already at work on The Maltese Falcon by the time The Dain Curse appeared in Black Mask. Why do you think Hammett abandoned, after all those years, not only the Op for Spade but also, and at the same time, a large detective agency (the Continental) for a small concern (Spade \& Archer) and, more importantly perhaps, a first-person for a third-person narrator?

RL: First, I think The Dain Curse is Hammett's weakest novel. It is pieced together from linked stories and though the writing is often strikingly good, it doesn't hold together structurally. I think he hurried it to Knopf to meet the terms of his two-book contract.

The Maltese Falcon is another matter. He said that in that book he was consciously trying to make "literature," or a serious statement of enduring value. $\mathrm{He}$ appropriated, reputedly from Henry James, the limited-third-person point of view, his first use of that technique. He crafted a story, using elements he had been experimenting with for as many as five years that resonated with meaning. He addressed the meaning and the consequences of principled behavior. By having Spade work for himself rather than an agency, he transferred the responsibility for the detective's ethical code from the agency to Spade as an individual. He wrote an existential novel: without guidance, Spade alone defines his code and is responsible for his behavior.

BT: According to you, Hammett was, in the late 1920s, "already recognized as a major force in America's most talented literary generation, the generation of Ernest Hemingway, F. Scott Fitzgerald, William Faulkner and John Dos Passos." (630) In this connection, I'd be grateful for your views on the vexed question of the Hammett-Hemingway relationship. Literary critics like Sheldon Grebstein have tended to paint the hardboiled school as "Hemingway's children." On the other hand, Frank Gruber wrote that "Hemingway's style, when he finally found it in The Sun Also Rises and A Farewell to Arms, is right out of Black Mask." Similarly, Raymond Chandler felt that "Hemingway may have learned something from Hammett." Do you agree with any of these views? Or were Hammett and Hemingway working simultaneously in the same direction, towards what Raymond Chandler called the "revolutionary debunking of both the language and material of fiction" that took place in the 1920s?

RL: I doubt that in the early days, that is before 1926 when The Sun Also Rises was published, either Hammett or Hemingway was aware of the other. Hammett read voraciously and broadly. The only early commentary either made about the other is in Hammett's story "The Main Death," when he has young Enid Gungen reading The Sun Also Rises. Flaming youth fiction, he seems to say. Later Hammett personally regarded Hemingway disdainfully, as a show-off and a bully. I can only guess that his personal feeling colored his reading of Hemingway's fiction.

So, in answer to your question, I think it is a considerable stretch to claim that either's writing influenced the other. They were, however, both riding the modernist currents of their time.

BT: With the publication of The Big Book of the Continental Op, and the material that you have collected in Return of the Thin Man and The Hunter (including some wonderful screen stories such as "On the Make," which are close to The Maltese Falcon in spirit if not in scope), can 
we now say that all of Hammett's stories, whether previously published or not, are finally made available?

RL: Three weeks ago, I would have said yes. Then I got a note from Julie Rivett informing me that a fireman/author named Daniel Robinson had bought a carton of old pulps at auction, including the November 1925 issue of True Police Stories, which included a previously unknown Hammett story. I bought the magazine from Robinson, and it is destined for the Hammett collection at the University of South Carolina. Maybe there is more-I hope so-but I have to believe that we have located most of it.

\section{AUTHOR}

BENOÎT TADIÉ

Université Rennes 2 